\title{
Temporal trends and determinants of fish biomass in two contrasting natural lake systems: insights from a spring long-term monitoring scheme
}

\author{
Anastasios Bounas ${ }^{1, *}$, Giorgos Catsadorakis ${ }^{2}$, Irene Koutseri ${ }^{2}$, Harris Nikolaou ${ }^{2}$, Delphine Nicolas ${ }^{3}$, \\ Myrsini Malakou ${ }^{2}$ and Alain J. Crivelli ${ }^{3, *}$ \\ ${ }^{1}$ Department of Biological Applications and Technology, University of Ioannina, Ioannina, 45110, Greece \\ 2 Society for the Protection of Prespa, Agios Germanos, 53150 Florina, Greece \\ ${ }^{3}$ Research Institute of Tour du Valat, Le Sambuc, 13200 Arles, France
}

Received: 29 April 2021 / Accepted: 23 June 2021

\begin{abstract}
Freshwater fish declines are triggered by a suite of anthropogenic threats, including habitat degradation, climate and land use change, biological invasions, pollution and overfishing. Robust monitoring schemes are needed to understand and detect any effects of different factors on freshwater fish abundance and to be able to predict and respond to potential stressors. Here, we used standardized biomassper-unit-effort (BPUE) data deriving from gillnet sampling over a 34-year period in the two Prespa Lakes and determined species trends using general additive models coupled with structural change models. Furthermore, the influence of seven environmental variables was assessed for each fish species using an analytical approach based on random forests. We showed that the total annual BPUE is increasing in Lake Mikri Prespa whereas it is stable in Megali Prespa and that the relative BPUE of introduced species in the former is increasing through the years. Differences in the lakes' trophic status were reflected in species trend patterns. Random forests showed that air temperature, the introduction of the invasive Lepomis gibbosus, predation and water management played a role in shaping species biomass in Mikri Prespa whereas abiotic factors are the main drivers of biomass changes in Megali Prespa. Our results provide empirical evidence on the importance of long-term monitoring in distinguishing between direct and indirect effects of large-scale stressors on fish abundance as well as insights towards sustaining the integrity of fish communities.
\end{abstract}

Keywords: Gillnet / invasive species / Prespa wetland / random forests / water management

\begin{abstract}
Résumé - Tendances et facteurs déterminants des variations temporelles des biomasses de poissons dans deux systèmes lacustres naturels contrastés : éléments issus d'un programme de surveillance à long terme réalisé au printemps. Le déclin des espèces de poissons d'eau douce résulte d'une multitude de menaces anthropogéniques, dont la dégradation des habitats, les changements du climat et l'utilisation des sols, les invasions biologiques et la surpêche. Des systèmes de surveillance robustes sont nécessaires pour comprendre les variations d'abondance de poissons et pour détecter, prévoire et faire face aux éventuels facteurs de stress identifiés. À partir de données de biomasse standardisées par unité d'effort (BPUE), provenant d'un échantillonnage réalisé au filet maillant sur une période de 34 ans dans les deux lacs de Prespa, ont été analysées les évolutions temporelles des espèces piscicoles en appliquant des modèles additifs généraux couplés à des modèles de changement structurel. De plus, l'influence de sept variables environnementales a été évaluée par espèce et par lac en utilisant une approche analytique basée sur des forêts d'arbres décisionnels. La BPUE annuelle totale augmente dans le lac Mikri de Prespa alors qu'elle est stable dans le lac Megali de Prespa. Au fil des ans, la BPUE relative des espèces introduites augmente dans le lac Mikri. Les différences de statut trophique entre les deux lacs se retrouvent dans les tendances observées par espèce. Les forêts d'arbres décisionnels ont montré que la température de l'air, l'introduction de l'espèce invasive Lepomis gibbosus, la prédation aviaire et la gestion de l'eau ont joué un rôle dans l'évolution de la biomasse des espèces à Mikri Prespa, tandis que les facteurs abiotiques sont les principaux moteurs des changements de biomasse à Megali Prespa. Ces résultats constituent des preuves empiriques de
\end{abstract}

\footnotetext{
*Corresponding author: abounas@uoi.gr; baluche9@gmail.com
} 
l'importance d'un suivi à long terme pour distinguer les effets directs et indirects des facteurs de stress à grande échelle sur l'abondance des poissons, et permettent de préconiser quelques suggestions pour maintenir l'intégrité des communautés de poissons.

Mots-clés : Filet maillant / espèces invasives / zone humide de Prespa / forêts d'arbres décisionnels / gestion de l'eau

\section{Introduction}

Freshwater ecosystems cover less than $9 \%$ of the global land area, yet they contribute approximately $40 \%$ of global annual renewable ecosystem services and are considered hotspots of biodiversity (Zedler and Kercher, 2005; Collen et al., 2014). Furthermore, inland waters are of outmost conservation importance as they hold almost half of all fish species (Arthington et al., 2016). Despite their value, these ecosystems are becoming heavily degraded, with freshwater biodiversity declining at a much faster rate than marine or terrestrial biodiversity (Collen et al., 2014), thus rendering inland waters one of the most imperiled habitats at a global scale (Dudgeon et al., 2006).

Freshwater fish declines are triggered mainly by anthropogenic impacts, including habitat degradation, climate and land use change, biological invasions, pollution and overfishing (Stendera et al., 2012; Reid et al., 2019). Habitat degradation encompasses a variety of interacting factors, with direct effects such as stream diversion for agricultural use, excavations and channel morphology alterations. However, indirect impacts as a result of intensive land-use practices can incur changes within the drainage basin; increased sediment and nutrient loads, and subsequent decreased water quality and reduction of habitat suitability, have been linked to declines in fish populations and alteration of freshwater communities (Pusey and Arthington, 2003; Darwall and Freyhof, 2016; Reid et al., 2019). Furthermore, human disturbances may increase the likelihood of invasion by nonnative species (Dudgeon et al., 2006; Lee et al., 2017) and such synergy, therefore, makes potential effects of non-native species difficult to pinpoint and predict. Although past research suggests that most introductions of non-native fishes could be quite harmless (Gozlan, 2008), there are many examples of large-scale impacts on native species through predation, competition, habitat alteration, hybridization and the transfer of parasites (Dudgeon et al., 2006; Arthington et al., 2016; Gallardo et al., 2016). Lastly, overfishing is regarded as a persistent freshwater threat. Although the magnitude of bycatch might be greater in marine systems, it also affects a wide range of freshwater taxa (Allan et al., 2005).

This diverse array of threats combined with the declining rates of freshwater fish highlight the need of robust monitoring schemes (Radinger et al., 2019). Analyses of temporal changes and trends in fish populations can be extremely useful in understanding the relationships between different biotic and abiotic factors and freshwater fish abundance as well as to detect the effects of these stressors. Such task, however, can be rather challenging due to the lack of long-term datasets (White, 2018). Ultimately, the examination of long-term trends in fish abundance can improve understanding of population fluctuations caused by either natural variation or anthropogenic influence and further augment the ability to diagnose, predict and respond to potential stressors (Radinger et al., 2019).

The Prespa wetland, formed by two natural lakes Mikri Prespa and Megali Prespa (Crivelli and Catsadorakis, 1997), is situated in south-eastern Europe between Albania, North Macedonia and Greece $(40.8 \mathrm{~N}, 20.9 \mathrm{E})$. The lakes are of Tertiary origin and among the oldest ones in Europe. They are located at 850 metres above sea level (m a.s.1.) enclosed by mountains rising to over $2500 \mathrm{~m}$ a.s.l. (Crivelli et al., 1997a). Mikri Prespa covers an area of $47.4 \mathrm{~km}^{2}$ and is a shallow (maximum depth of $8 \mathrm{~m}$ ) eutrophic lake with no permanent streams. The lake has limited outflow into Lake Megali Prespa through a narrow semi-artificial channel at its north-western side; additionally, a channel was dug in the southern part of the lake for irrigation purposes and operated for almost three decades (ca 1976- early 2000; Crivelli, 1990; Hollis and Stevenson, 1997). On the other hand, Megali Prespa is a much larger $\left(253.6 \mathrm{~km}^{2}\right)$ and deeper (maximum depth of $55 \mathrm{~m}$ ) mesotrophic lake with several permanent tributaries. The only natural outlet is an underground karstic connection with Ohrid lake (Matzinger et al., 2006). The region is internationally recognized as one of Europe's most ecologically important areas or biodiversity "hotspots" and its fish fauna is characterized by high endemism (Crivelli, 1997a; Wagner and Wilke, 2011). Human action has affected the lakes throughout the years, especially Mikri Prespa, with main impacts on its hydrological system through water irrigation and regulation: until the mid ' 60 s the two lakes' water levels were equal and jointly fluctuated but over the course of years a sluice was placed in the semi-artificial channel permitting Lake Mikri Prespa to stand above Lake Megali Prespa with water outflowing to the latter when necessary. The channel was eventually reconstructed into a concrete deep and narrow channel and a sluice gate was installed and operated since 2005 to regulate water level aiming to sustain both local economy and the lake's good ecological status (Hollis and Stevenson, 1997; Parisopoulos et al., 2009). Furthermore, the area used to support an important fishery but eventually fishing intensity has dropped, reflecting overall patterns of inland fisheries in Europe (Cowx, 2015). Active traditional fishing methods, such as the "pelaizia", have been abandoned since the early 2000 s (Crivelli et al., 1997a; Catsadorakis et al., 2018). Finally, several non-native species were introduced through the years (Shumka and Apostolou, 2018) but only two invasive ones are currently established; the Topmouth gudgeon (Pseudorasbora parva), appeared in the 1970s and its abundance had increased significantly by the 1990s (Crivelli, 1990; Rosecchi et al., 1993 ) and the Pumpkinseed (Lepomis gibbosus) that was first observed in the lakes in 1996.

The aim of this study is to summarize long-term patterns in fish biomass data of Prespa Lakes, collected over a period of 34 years, to identify the factors that play a role in shaping species- 
A. Bounas et al.: Knowl. Manag. Aquat. Ecosyst. 2021, 422, 28

Table 1. Average values and standard deviations (sd) of the environmental variables for both lakes.

\begin{tabular}{|c|c|c|c|c|c|}
\hline \multirow[t]{2}{*}{ Variable } & \multirow[t]{2}{*}{ Abbreviation } & \multicolumn{2}{|c|}{ Mikri Prespa } & \multicolumn{2}{|c|}{ Megali Prespa } \\
\hline & & Mean & SD & Mean & SD \\
\hline Monthly average temperature $\left({ }^{\circ} \mathrm{C}\right)$ & t.air & 15 & 4.2 & 15.2 & 4.3 \\
\hline Monthly total precipitation (mm) & precipitation.mm & 41.4 & 27.5 & 40.6 & 29.8 \\
\hline Monthly average water level (m a.s.1.) & water.level & 854.1 & 0.4 & 844.6 & 0.7 \\
\hline Monthly average secchi disk (m) & secchi & 1.7 & 0.6 & 3.23 & 1 \\
\hline Number of piscivorus birds (breeding pairs) & predation & 663.5 & 482.5 & 1709.4 & 343.4 \\
\hline Water management (before/after 2005) ${ }^{\dagger}$ & water.management & & & & \\
\hline Introduction of Lepomis gibbosus (before/after 1996) & lepomis.intro & & & & \\
\hline
\end{tabular}

${ }^{\dagger}$ Only applicable for Mikri Prespa.

specific biomass trends and to disentangle the direct and indirect effects of various large-scale ecological stressors in the two different (ecologically and human-impacted) natural lake systems. Besides serving as a case study for quantifying the relative effects of different anthropogenic impacts at important areas for conservation, the results of the present study can be used to assist the development of effective management strategies.

\section{Material and methods}

\subsection{Sampling}

Data were collected for 26 monitoring years from 1984 to 2017 (1984-1985, 1990-1994, 1996-1998, 2000, 2002-2013, 2015-2017) in Lake Mikri Prespa and for 13 monitoring years from 1996 to 2017 (1996-1998, 2007-2013, 2015-2017) in Lake Megali Prespa. Gillnet monitoring was carried out three times per year (April, May, June) in both lakes to cover the whole spawning season. Sampling stations in each lake were located in the littoral zone; a shallower area $(0.5-5 \mathrm{~m})$ with a gravelly substrate and scattered vegetation in Mikri Prespa and a station close to the shore $(0.9-2.2 \mathrm{~m})$ with a sandy substrate near a stream outlet in Megali Prespa. Due to increase in macrophyte cover that interfered with gillnet setting, from 2015 onwards the sampling station in Mikri Prespa was relocated $150 \mathrm{~m}$ away. Two sets of $50 \mathrm{~m}$ monofilament gill-nets with 10 mesh sizes $(10,14,18,23,27,32,38,45,52$ and $60 \mathrm{~mm}$ ) were deployed perpendicularly to the coast in both lakes. Nets were set for two consecutive days and were visited daily. All fish were measured (fork length in $\mathrm{mm}$ ), weighed (g) and sexed. For each sampling event, catches were standardized as biomass-per-unit-effort (BPUE) calculated as the aggregated weight of fish captured in each mesh size $(\mathrm{g})$ per mesh surface area $\left(\mathrm{m}^{2}\right)$ and fishing duration (in hours). Before the statistical analyses BPUE values were transformed as: $\log _{10}$ (BPUE +1$)$ to reduce the influence of exceptionally high biomass values.

\subsection{Environmental variables}

To investigate which environmental factor(s) may affect each species BPUE, we identified and collected data on 7 predictor variables characterizing abiotic, biotic and humaninduced processes (Tab. 1). Monthly average air temperature and monthly total precipitation from 1984 to 2017 were retrieved from the meteorological stations located between the two lakes, and run by the Power Public Corporation S.A. Hellas, the Society for the Protection of Prespa (SPP) and the Ministry of Environment, Energy and Climate Change (https:// kyy.hydroscope.gr/stations/d/200166/). Monthly data of the average water level for both lakes were collected throughout all years by the SPP as part of their long-term monitoring scheme. To quantify any predation pressure on fish abundance, we used the number of piscivorous birds (in breeding pairs) as a proxy (SPP, unpublished data): for Mikri Prespa we included numbers of Pygmy Cormorant (Microcarbo pygmaeus) whereas for Megali Prespa we included pairs of both Dalmatian Pelican (Pelecanus crispus) and Great Cormorant (Phalacrocorax carbo), since these species differentially forage in each lake (Hatzilacou, 1993; Willems and de Vries, 1998). For each fishing month, Secchi disk transparency measurements were also recorded $(20 \mathrm{~cm}$ diameter disc, ten replicates each time). The introduction of Lepomis gibbosus that took place in 1996 was included as a categorical variable with two levels (before/after 1996). Finally, a categorical variable for water management was included (before/after 2005) only for Mikri Prespa, where a reconstructed sluice gate regulating the flood of the littoral zone operates since January 2005.

\subsection{Data analysis}

Previous investigation on net selectivity (Boy and Crivelli, 1988; Crivelli et al., 1997a) showed that some fish taxa are incorrectly sampled using the above method, since only the largest individuals can be caught in the $10 \mathrm{~mm}$ mesh size. Therefore, we limited our data analysis to a total of 10 species, seven of them native: Prespa spirlin (Alburnoides prespensis), Prespa bleak (Alburnus belvica), Prespa barbel (Barbus prespensis), Prespa nase (Chondrostoma prespense), European carp (Cyprinus carpio), Prespa roach (Rutilus prespensis), Prespa chub (Squalius prespensis), and three introduced: Prussian carp (Carassius gibelio), Pumpkinseed (Lepomis gibbosus) and the Tench (Tinca tinca). Although not an indigenous species, we considered Cyprinus carpio as native in the area as it was first introduced since Greco-Roman times (Barbieri et al., 2015). Furthermore, Tinca tinca was not considered in the analyses for Lake Megali Prespa as it was rarely caught.

BPUE data can show periodic signals and non-linear patterns of temporal change, thus a General Additive Model 


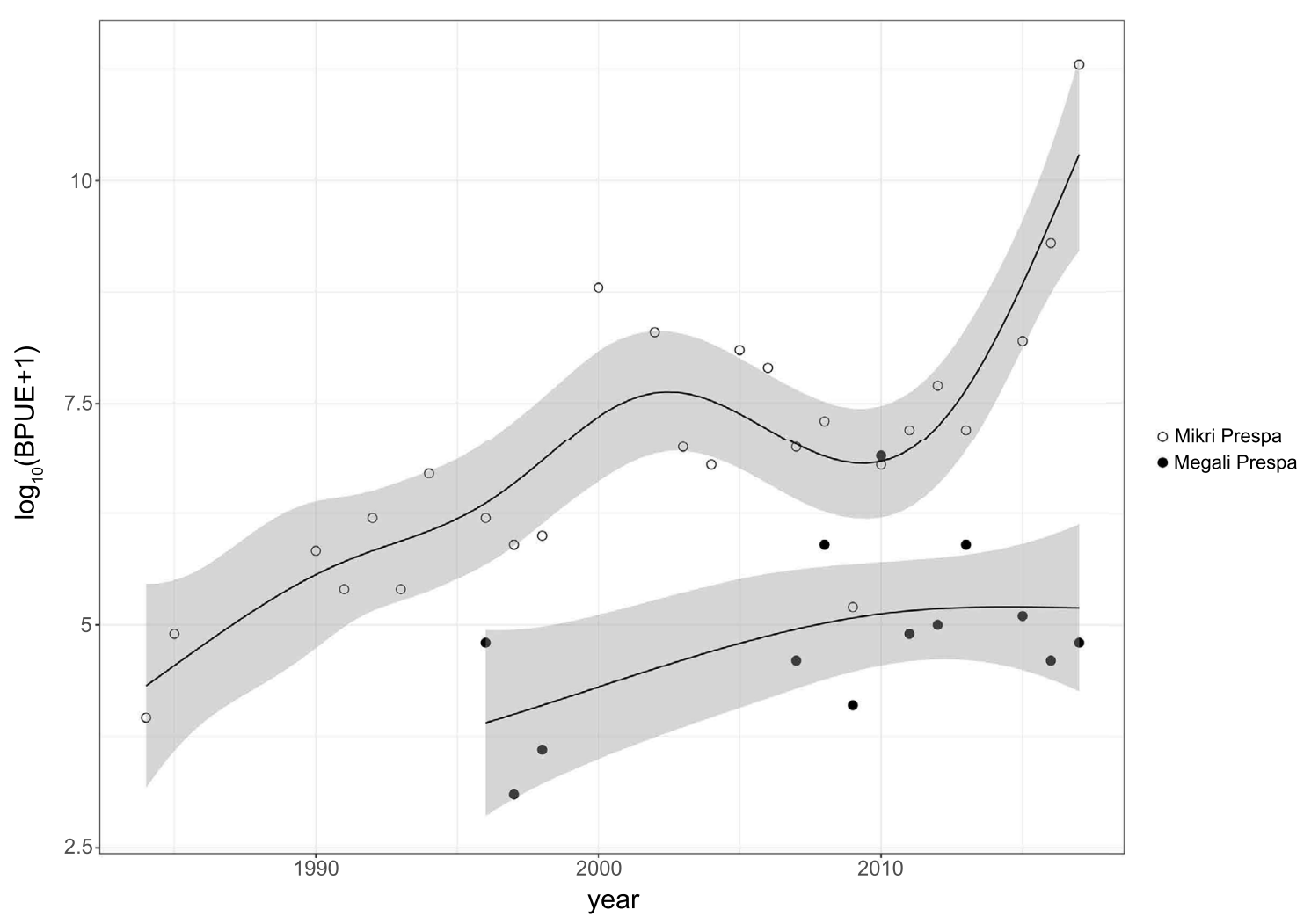

Fig. 1. Time series of mean annual catches expressed as biomass per unit effort (BPUE), for Mikri Prespa (open dots) and Megali Prespa (filled dots). Black line shows the smoothed trend and shaded areas show the $95 \%$ confidence limits.

approach (GAM) was used to model the overall and specieslevel temporal BPUE trends as a smooth nonlinear function of time. GAMs were built in the "mgcv" package (Wood, 2018) in R 3.6.2 (R Core Team, 2019) using the Restricted Maximum Likelihood (REML) estimation method. Since the relocation of the sampling station in Mikri Prespa after 2015 could have influenced BPUE trends, we tested for such effect by examining any structural changes in the mean of the monthly BPUE changes over time. The analysis was performed using the "strucchange" R package (Zeileis et al., 2002). Tests against changes were conducted using the Ordinary Least Squares (OLS)-based cumulative sum (CUSUM) process and the corresponding significance test. When significant results were obtained, changes were dated by applying the function 'breakpoints' which allows for the simultaneous estimation of multiple breakpoints along with their respective 95\% confidence intervals (Zeileis et al., 2003). The optimum number of breakpoints in each species trend was evaluated using the Bayesian Information Criterion (BIC). When a breakpoint (along with its confidence intervals) included 2013 for any species (no fishing occurred in 2014), BPUE data for years 2015-2017 were not included in subsequent analyses.

The influence of environmental variables was assessed for all fish species in both lakes using an analytical approach based on random forests. A random forest is a powerful machinelearning algorithm based on regression/classification tree ensembles that does not require assumptions such as linear or nonlinear relationships between predictors and response factors (Breiman, 2001; Cutler et al., 2007). Models were fitted using the R package 'randomForest' (Liaw and Wiener,
2002) using 500 trees and two random variables at each split. Model performance was assessed based on its respective Mean of Squared Residuals (MSR) and pseudo $R^{2}$. Furthermore, we used the R package "rfUtilities" (Evans and Murphy, 2015) to perform significance tests on the built models. The importance of the predictors was tested for statistical significance $(p<$ 0.05) using a permutation approach (Altmann et al., 2010) as implemented in the R package "pRF" (Chakravarthy, 2016). The number of permutations was set to 1000 . The permuted importance values of environmental factors influencing the biomass of fish species were then rescaled from 0 to 100.The variable regarding predation (number of breeding pairs), that showed high variation was square-root transformed before the data analysis. Finally, the direction and magnitude of the effect of the most important variables on BPUE was evaluated through partial dependence plots (Elith et al., 2008).

\section{Results}

Total annual BPUE in Lake Mikri Prespa showed an increasing trend through the years $\left(R_{\text {adj. }}^{2}=0.75, p<0.001\right)$ whereas total annual BPUE was found to be rather stable in Megali Prespa $\left(R_{\text {adj. }}^{2}=0.23, p=0.15\right.$; Fig. 1$)$. Mean annual BPUE values were constantly higher in Mikri Prespa compared to those of Megali Prespa $(t=5.28, \mathrm{df}=12, p<$ $0.001)$. The highest overall mean BPUE in Mikri Prespa took place in June, with a value of $177.7 \mathrm{~g} \mathrm{~h}^{-1} \mathrm{~m}^{-2}$, although May was also a prolific fishing month with a mean BPUE value of $165.1 \mathrm{~g} \mathrm{~h}^{-1} \mathrm{~m}^{-2}$. On the other hand, May held the highest 

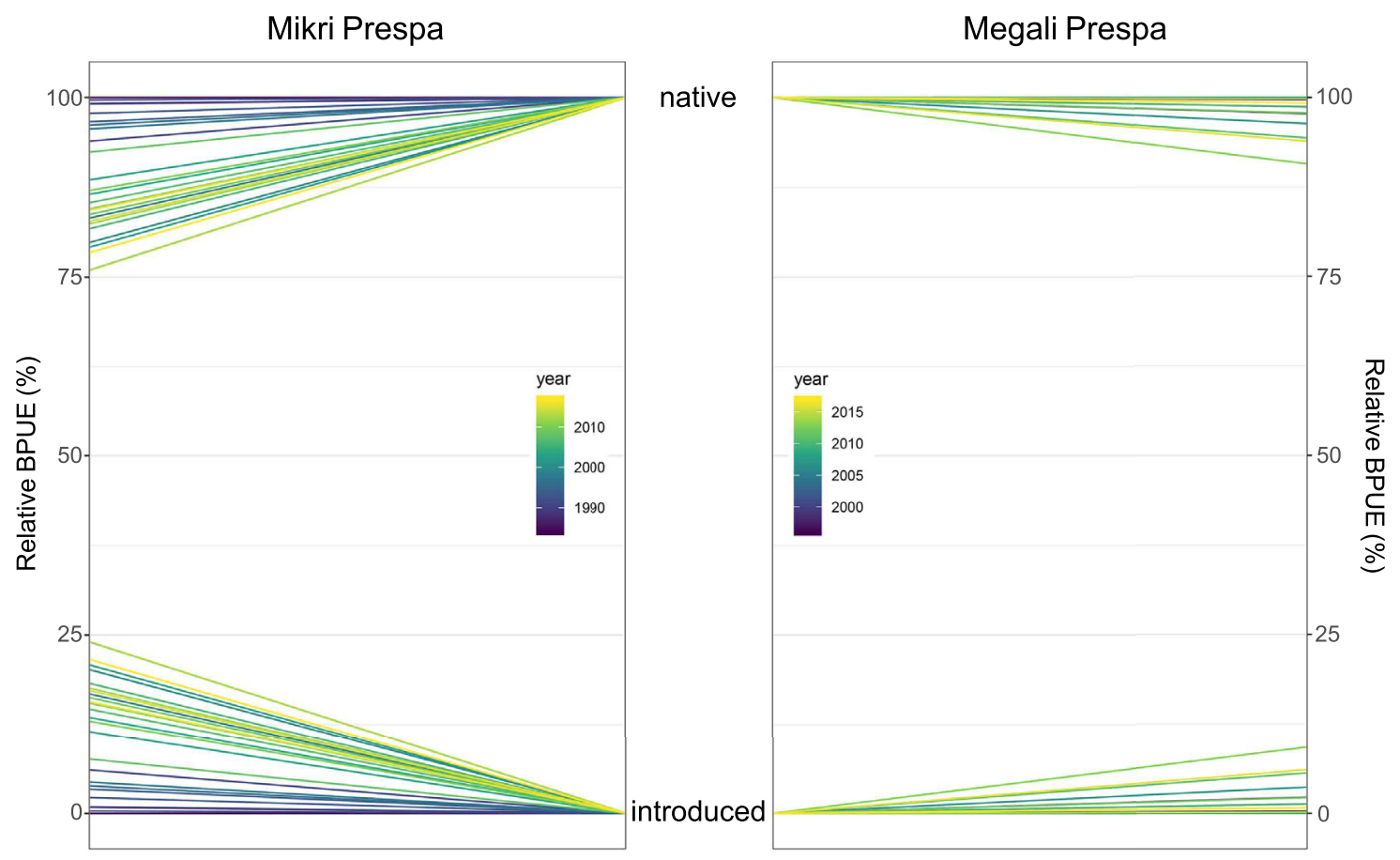

Fig. 2. Parallel coordinates plots of relative BPUE (expressed as a percentage of the total annual BPUE) for each fishing year and lake.

BPUE in Megali Prespa with a mean value of $171.3 \mathrm{~g} \mathrm{~h}^{-1} \mathrm{~m}^{-2}$ (Tab. S1). At the species-level, Alburnus belvica was the most prominent species in Mikri Prespa with an overall mean annual BPUE of $73.9 \mathrm{~g} \mathrm{~h}^{-1} \mathrm{~m}^{-2}$, comprising $65.8 \%$ of the total annual BPUE. In Lake Megali Prespa, Rutilus prespensis was the species with the highest mean annual BPUE $\left(48.9 \mathrm{~g} \mathrm{~h}^{-1} \mathrm{~m}^{-2}\right.$, $49.9 \%$ of total annual BPUE; Tab. S1). When examining BPUE from a species provenance perspective (native/ introduced), it seems that the relative BPUE of introduced species is increasing through the years in Mikri Prespa where they were found to comprise more than $20 \%$ of the total BPUE in 2017, in contrast to less than 1\% until 1990 (Fig. 2). However, no such process was evidenced in Megali Prespa.

There was high species-specific variation in BPUE trends during the monitoring scheme (Fig. 3). In Lake Mikri Prespa, only two out of 10 species were found to have stable trends, Chondrostoma prespense $\left(R_{\text {adj. }}^{2}=0.03, p=0.29\right)$ and Rutilus prespensis $\left(R_{\text {adj. }}^{2}=0.03, p=0.07\right)$. The BPUE of both Alburnoides prespensis and Barbus prespensis showed an overall decreasing trend $\left(R_{\text {adj. }}^{2}=0.57, p<0.001 ; R_{\text {adj. }}^{2}=0.31\right.$, $p<0.001$ respectively). Although Alburnus belvica BPUE showed a high variation within years, overall it presented an increasing trend $\left(R_{\text {adj. }}^{2}=0.04, p<0.05\right)$. The BPUE of Carassius gibelio showed a slight increase until $2005(95 \%$ CIs $=2004-2013)$, followed by a decline $\left(R_{\text {adj. }}^{2}=0.15, p<\right.$ 0.05). Lepomis gibbosus BPUE increased abruptly since its introduction in 1996, reaching a mean annual BPUE value of $18.4 \mathrm{~g} \mathrm{~h}^{-1} \mathrm{~m}^{-2}$ in 2002. After that, BPUE fluctuated irregularly with high variation between years $\left(R_{\text {adj. }}^{2}=0.43\right.$, $p<0.001)$. Squalius prespensis and Cyprinus carpio also showed fluctuations in BPUE through time; although for Squalius prespensis an overall slight increase was identified $\left(R_{\text {adj. }}^{2}=0.27, p<0.001\right)$, this was not the case for Cyprinus carpio. Its BPUE first increased in the early ' $90 \mathrm{~s}$, then slightly declined before increasing again reaching its maximum observed BPUE in May 2008 with $34.7 \mathrm{~g} \mathrm{~h}^{-1} \mathrm{~m}^{-2}$. Despite these fluctuations the species overall BPUE showed an increasing trend $\left(R^{2}\right.$ adj. $\left.=0.51, p<0.001\right)$. Finally, Tinca tinca showed a slight increase through the years $\left(R_{\text {adj. }}^{2}=0.55, p<\right.$ 0.001 ). It should be noted that for three species (Alburnoides prespensis, Barbus prespensis and Tinca tinca) a common breakpoint was identified around 2012-2013, which is consistent with the change in the sampling station as stated in the methods section. In Lake Megali Prespa, trends in BPUE were more straightforward (Fig. 3b). Four out of nine species examined showed stable trends in BPUE (Alburnus belvica, $R_{\text {adj. }}^{2}=0.01, \quad p=0.26 ;$ Barbus prespensis, $R_{\text {adj. }}^{2}=0.02$, $p=0.93$; Chondrostoma prespense, $R_{\text {adj. }}^{2}=0.02, p=0.56$; Lepomis gibbosus, $R_{\text {adj. }}^{2}=0.04, p=0.13$ ). Another four species showed increasing BPUE trends (Carassius gibelio, $R_{\text {adj. }}^{2}=0.22, p<0.05 ;$ Cyprinus carpio, $R^{2}$ adj. $=0.17, p<0.05$; Rutilus prespensis, $R^{2}$ adj. $=0.13, p<0.05$; Squalius prespensis, $R_{\text {adj. }}^{2}=0.27, p<0.05$ ), whereas Alburnoides prespensis was the sole species found to be in slight decrease $\left(R_{\text {adj. }}^{2}=0.12\right.$, $p<0.05)$.

Random forest model performance differed considerably across species. In Mikri Prespa, models performed poorly for three out of ten species, Carassius gibelio $(\mathrm{MSE}=0.03$, $\left.R^{2}=0.01, p=0.07\right)$, Rutilus prespensis (MSE $=0.07, R^{2}=$ $-0.05, \quad p=0.18)$ and Squalius prespensis (MSE $=0.07$, $R^{2}=0.03, p=0.06$ ). In Megali Prespa models explained none of the variation for five out of nine species: Alburnoides prespensis $\left(\mathrm{MSE}=0.09, R^{2}=-0.07, p=0.12\right)$, Barbus prespensis $\left(\mathrm{MSE}=0.03, R^{2}=-0.25, p=0.67\right)$, Carassius gibelio $\left(\mathrm{MSE}=0.08, R^{2}=-0.12, p=0.32\right)$, Rutilus prespensis $(\mathrm{MSE}=$ $\left.0.29, R^{2}=0.001, p=0.06\right)$ and Squalius prespensis $(\mathrm{MSE}=$ $0.1, R^{2}=0.001, p=0.06$ ). Five environmental variables showed an influence on seven species' BPUE in Mikri Prespa 

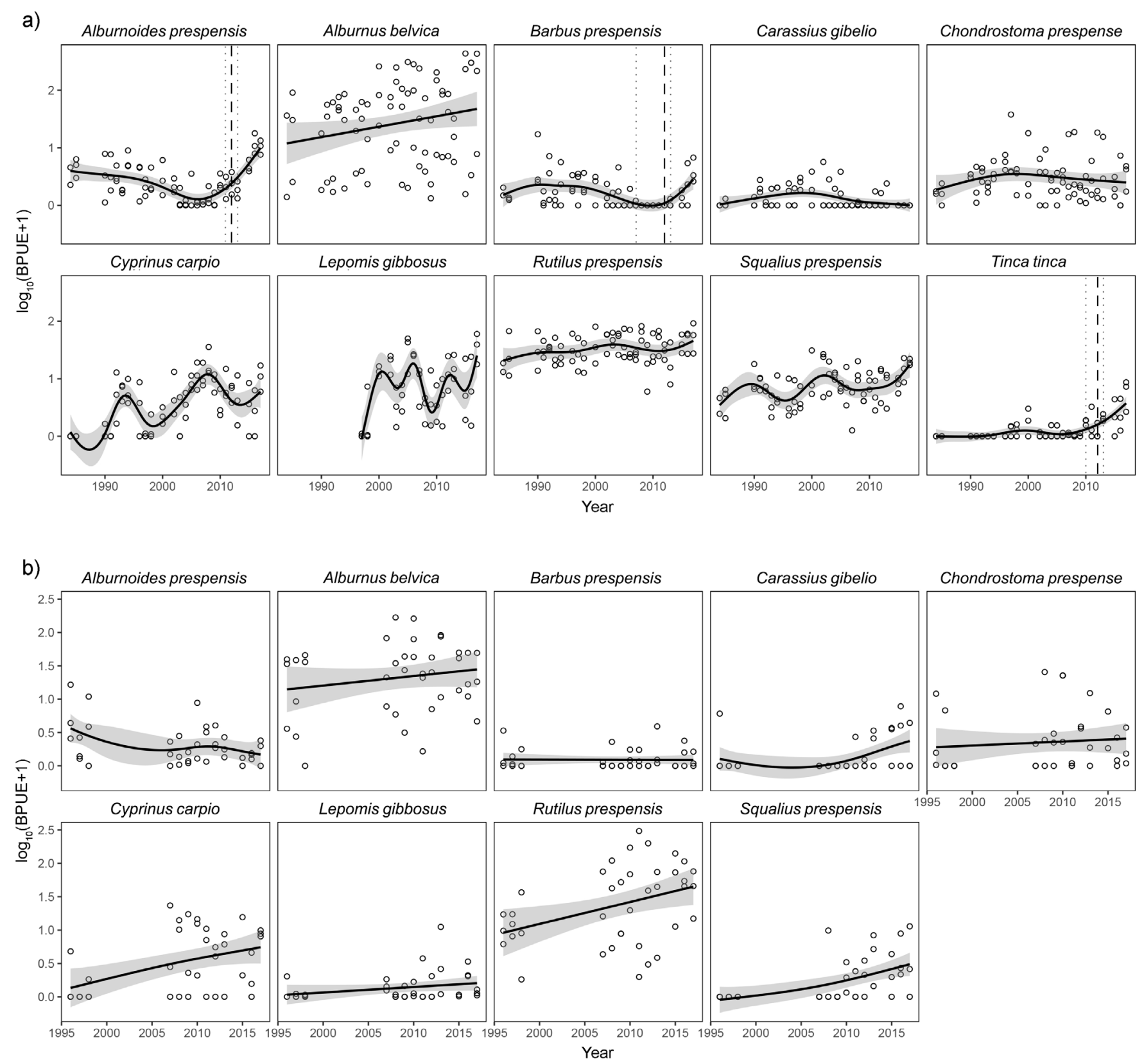

Fig. 3. Smoothed BPUE trends (black lines) along with $95 \%$ confidence limits (shaded areas) for all species examined in a) Mikri Prespa and b) Megali Prespa. Vertical dashed lines correspond to structural change points (along with $95 \%$ CIs in vertical dotted lines) attributed to the station relocation.

whereas only two variables showed a significant importance for four species in Megali Prespa (Fig. 4). Air temperature was the factor that affected most species in both lakes (Fig. 5). In Mikri Prespa both Alburnus belvica and Lepomis gibbosus BPUE showed a positive relationship with increasing temperature while Chondrostoma prespense showed the opposite pattern. The exact same relationships between BPUE of these three species and temperature were also obtained for Megali Prespa, with the addition of Cyprinus carpio, which showed the highest BPUE values in temperatures above $20^{\circ} \mathrm{C}$. The introduction of Lepomis gibbosus in 1996, seems to have a negative impact on Alburnoides prespensis BPUE (Wilcoxon rank sum test: $p<0.001$; Fig. 5a). Tinca tinca showed an increase after Lepomis introduction but based on the trend analysis this is a correlation rather than causal relationship. Water management in Mikri Prespa seems to be beneficial for Cyprinus carpio but quite detrimental for Barbus prespensis, with the species' mean BPUE in the period 2005-2017 being 95\% lower than that from 1984 to 2004 (Wilcoxon rank sum test: $p<0.001$; Fig. 5a). Predation by piscivorous birds (Microcarbo pygmaeus) in Mikri Prespa was found to be important for Cyprinus carpio and Tinca tinca BPUE, showing 


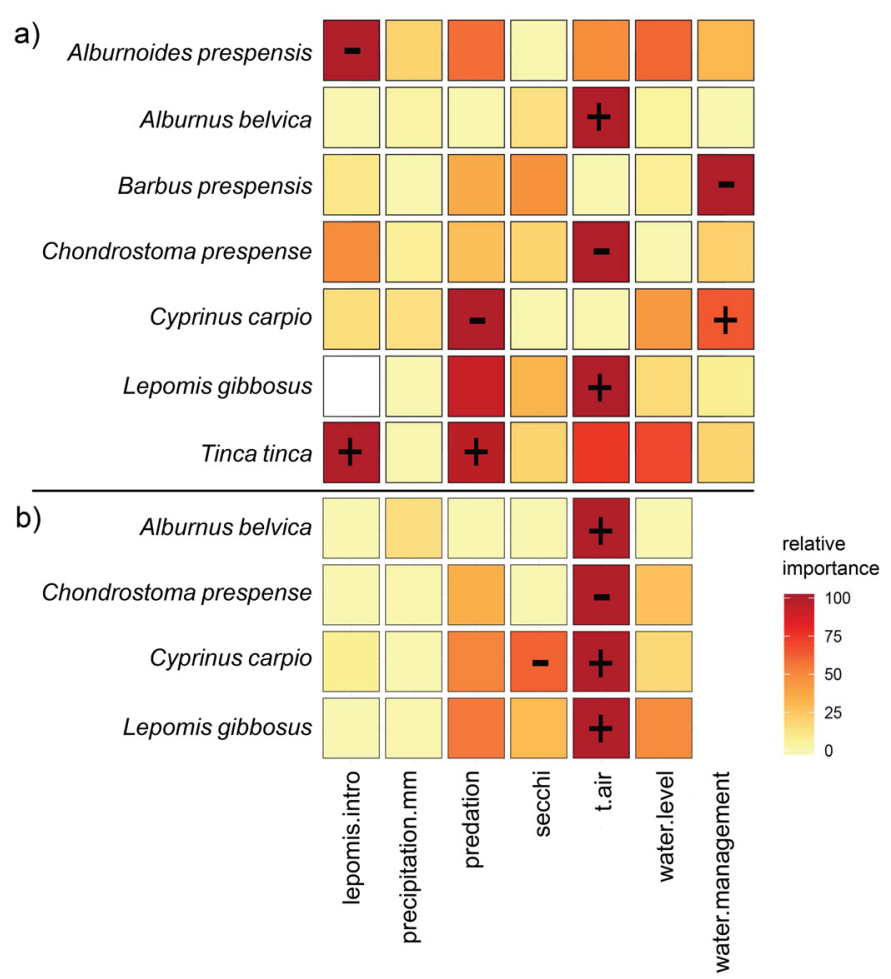

Fig. 4. Relative importance of environmental variables in the BPUE of species for a) Mikri Prespa and b) Megali Prespa, based on the Random Forest models. Descriptions of environmental factors are presented in Table 1. Plus $(+)$ and minus $(-)$ symbols show the direction of the effect (positive and negative respectively) only for variables with statistically significant importance after 1000 permutations.

a negative relationship with the former and a positive one with the latter, which most probably is another correlation rather than causation. Finally, Cyprinus carpio BPUE in Mikri Prespa was found to be negatively affected by water level, whereas the species BPUE displayed high values when Secchi disk transparency was low in Megali Prespa.

\section{Discussion}

Considering that Prespa Lakes host a fish community dominated by cyprinids, results are in accordance with the different trophic status of the lakes. Research has shown that cyprinids dominate highly productive lakes (Persson et al., 1991) due to their omnivory and efficiency in zooplankton predation as well as their ability to adapt to turbid waters (Persson et al., 1991; Schiemer and Wieser, 1992). On the other hand, in the temperate lakes of Europe usually percids are expected to be the most abundant species in mesotrophic waters but they are not common in Greece (Crivelli, 1992). However, Rutilus rutilus, a cyprinid species, has also been found to strongly dominate mesotrophic lakes (Olin et al., 2002), as is the case in Lake Megali Prespa where Rutilus prespensis shows the greatest increase in BPUE over time (Fig. 3). In fact, our results suggest that lower values of Secchi disk transparency in Megali Prespa, are associated with increased biomass of Cyprinus carpio (Fig. 5). Since eutrophication can induce changes in biotic and abiotic environmental factors it is expected that eutrophic lakes would show less stability than mesotrophic ones and this could be reflected in species trend patterns: in Mikri Prespa only two species showed stable trends, two were found to be decreasing whereas the rest six species showed an increase albeit with several fluctuations. Contrastingly, in Megali Prespa four species were found to be stable in terms of BPUE and only one showed a significant decline (Fig. 3). A significant increase in the biomass of introduced species was observed in Mikri Prespa (Fig. 2), that is mainly driven by Lepomis gibbosus. Though the species first appeared in 1996, it showed the greatest increase over time in Lake Mikri Prespa and by 2002 its population had become well-established. In 2017 the species BPUE had more than doubled, making it the third most abundant species in the lake. It should be noted, especially since we used biomass-based estimates (BPUE) from gillnet sampling, that some underestimation may have taken place regarding both the smaller individuals (as mentioned in the methods section; Olin et al., 2009) and the larger individuals of some fish species (i.e. Cyprinus carpio, Tinca tinca; Šmejkal et al., 2015). However, since gillnet sampling was constantly used throughout the study period, data are sufficient to calculate species trends and provide an informative assessment of factors that shape them.

The analyses of the possible impact of environmental factors on fish biomass further reflect the differences between the two lake systems; more factors seem to be implicated in explaining species trends in the smaller, shallower and more variable Mikri Prespa than in the larger, more stable Megali Prespa (Fig. 4). Additionally, the high variation in BPUE that was predominantly higher for the rarer species has probably incurred difficulties in isolating any significant factor for them. It should be further noticed that despite the large number of monitoring years encompassed in this study, the strength of the detected environmental effects should generally be interpreted in relation to the seasonal sampling duration that only covers the spawning period. Air temperature was the most prominent environmental factor shaping the biomass patterns of species in both lakes. In general, our results on the effect of temperature in BPUE should firstly be interpreted as reflecting the activity patterns of species rather than a long-term effect. Our sampling scheme using gill-nets is a passive method and therefore catches are intertwined with spawning timing that is temperature-driven. Chondrostoma prespense was the only species that showed high values of BPUE in lower temperatures, a result further reflected in the species monthly BPUE patterns with the highest values occurring always in April in both lakes. This is congruent with the species' ecology, as Chondrostoma prespense does spawn in late March to May with optimal temperatures ranging between 10 and $15^{\circ} \mathrm{C}$ for embryo and larvae development respectively (Crivelli et al., 1997b; Souchon and Tissot, 2012). Although stability of the species' trend in both lakes indicates that increasing temperature has not affected population biomass over the years, the species could face severe difficulties coping with future climate warming scenarios due to increased mortality of eggs and larvae (Kamler et al., 1998). Like other Cyprinids, Alburnus belvica and Cyprinus carpio BPUE proved to be enhanced by warmer temperatures, as was the BPUE of Lepomis gibbosus. Warmer temperatures have been found to 
a)
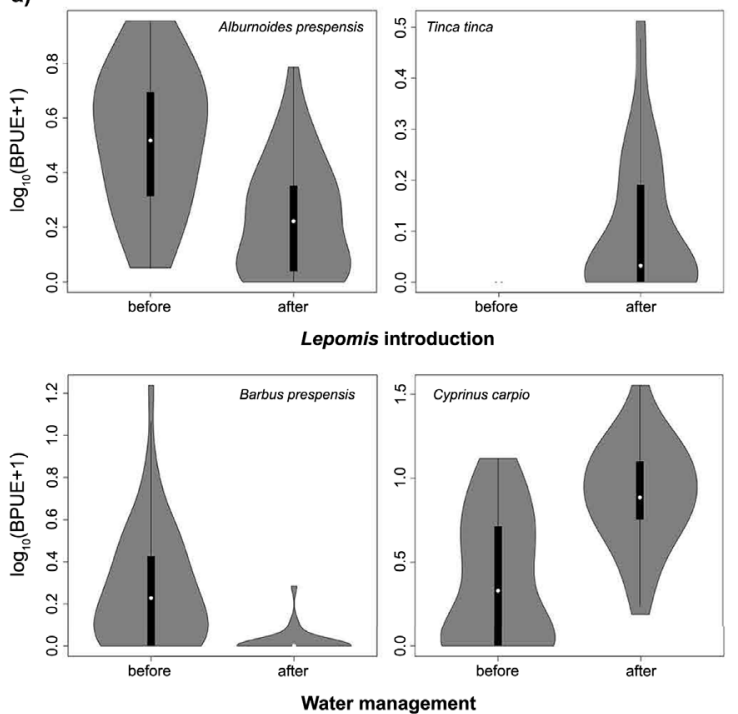

b)
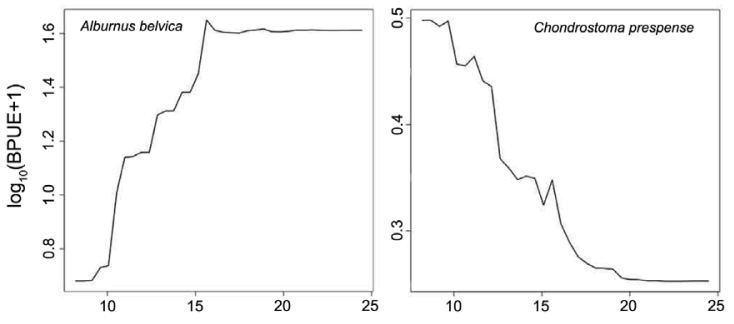
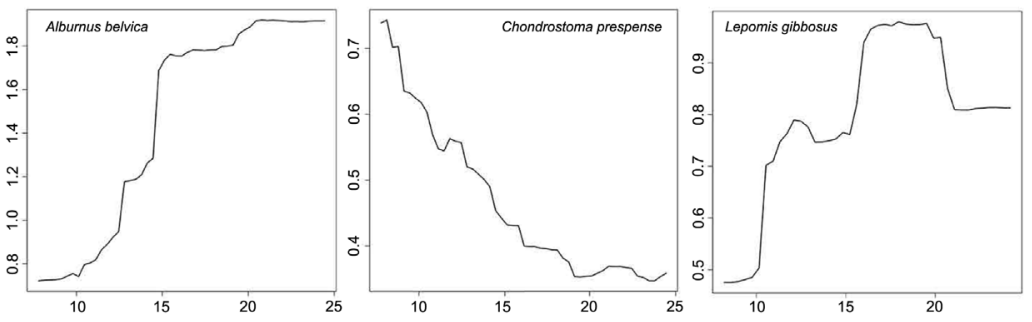

Air temperature $\left({ }^{\circ} \mathrm{C}\right)$
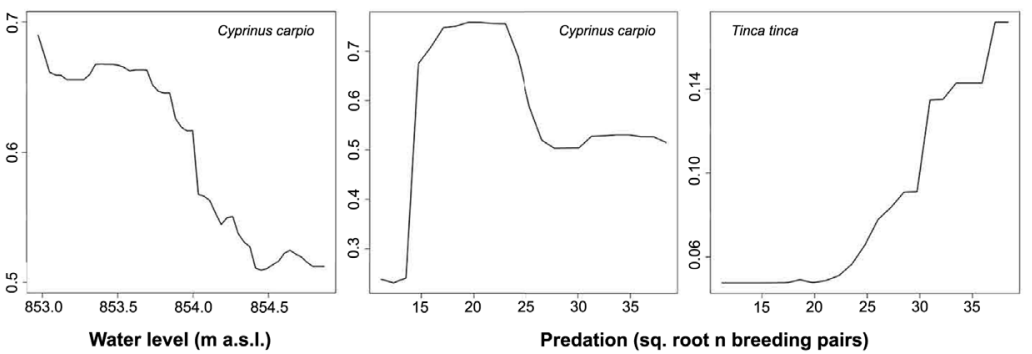

Predation (sq. root $\mathbf{n}$ breeding pairs)
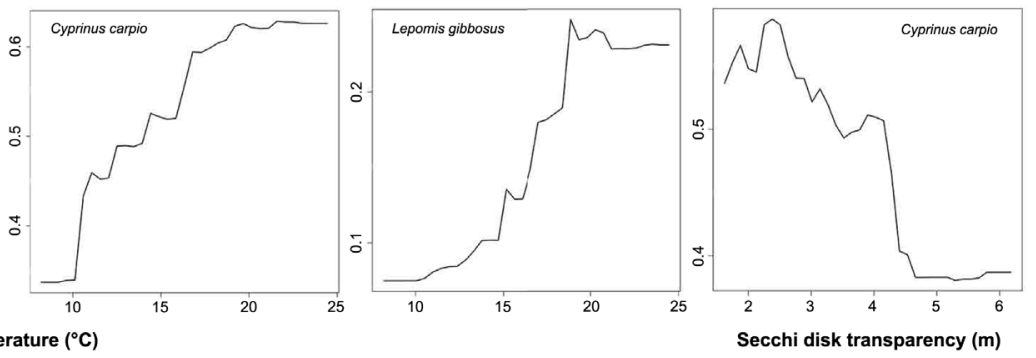

Fig. 5. Partial dependence plots showing the relationship between biomass per unit effort (BPUE) and significant environmental variables for a) Mikri Prespa and b) Megali Prespa.

favour a longer breeding season and earlier maturity for Lepomis gibbosus (Fox and Crivelli, 2001), while warmer climate is predicted to benefit the species recruitment thus increasing interactions with native fish species in the future (Zięba et al., 2015; Copp et al., 2017).

However, some effects of the introduction of Lepomis gibbosus may already be apparent since the long-term monitoring of the lakes made it possible to pinpoint the exact year when the introduction of the species took place. Our results suggest that the species' introduction constitutes an important stressor affecting the endemic Alburnoides prespensis BPUE with the beginning of its decline coinciding with the period of Lepomis establishment in Mikri Prespa. Disentangling causes of change in native fish communities can be very challenging since freshwater ecosystems are subject to both anthropogenic habitat modifications and nonnative species invasions, often at the same time. An interesting approach to non-native species effects on native ecosystems is the driver versus passenger models proposed by MacDougall and Turkington (2005). According to these models, non-native species may act either as direct drivers of change or as "passengers", successfully establishing populations but having low or no effects on ecosystems already affected by other noninteractive factors. In the case of Mikri Prespa, Pseudorasbora parva that was introduced in the 1970s may have played the "passenger" role, as despite the fact that its diet overlaps with that of Alburnoides prespensis, no population declines had been observed until the 1990s (Rosecchi et al., 1993). The subsequent introduction of Lepomis therefore, could work in synergy and thus represent an additional pressure through food resource competition (van Kleef et al., 2008; Almeida et al., 2014; Copp et al., 2017). Although the species has been introduced and adapted successfully in several freshwater ecosystems in Greece (Economidis et al., 2000), its potential impacts are largely unknown (Perdikaris et al., 2016). However, declines in the abundance of native fish species after Lepomis gibbosus introduction has been recently reported from another lake in Greece (Bobori et al., 2019), where it was found to compete with most native cyprinids.

Our results suggest that Barbus prespensis experienced a severe reduction in BPUE through the years with water management being the main driver behind this decline. This result should be interpreted with caution; the fact that after the relocation of the sampling station in 2013 in a less macrophyteinfested area the species BPUE showed an increase, suggests that the species abundance might not be depleted yet. However, these facts provide evidence of an indirect effect of water management. Barbus species are lithophilus, spawning in littoral areas with gravelly and sandy substrate (Catsadorakis et al., 1996). Increased vegetation in the littoral zone could have been triggered before the beginning of water management as a result of increased eutrophic conditions. 
Then, the sluice gate has been regulating water level since 2005 , leading to less extreme fluctuations in the flooding of the littoral zone (Fig. S1) and subsequently to increased vegetation (Evtimova and Donohue, 2016), thus restricting species' access to inundated bare substrates needed for successful reproduction (Probst et al., 2009; Britton and Pegg, 2011). Therefore, suitable spawning habitats may disappear under the present water management, rendering Barbus prespensis of future conservation concern. Revisiting the indicators developed for the evaluation of lake level control (Parisopoulos et al., 2009), should also be prioritized. On the other hand, water management seems to be quite positive for Cyprinus carpio. This seems to be a rather contradictory result, since the species' successful reproduction largely depends on the existence of well-flooded wet meadows in the area (Kazoglou et al., 2004). In fact, a remarkably successful breeding in 1991 coincided with a high spring water level of almost $855 \mathrm{~m}$ a.s.l., much higher than a water level value of $854.6 \mathrm{~m}$ a.s.l. which is considered as the minimum for highly successful spawning (Crivelli et al., 1997a; Fig. S2). Our random forest models, however, suggest that species biomass is higher at lower water levels, indicating that satisfactory Cyprinus recruitment is possible under the current management regime (Fig. S2). It should be noted that water management is probably not the sole reason responsible for the species' increased BPUE. By the beginning of water management the species had already started to recover probably due to the exceptional breeding year mentioned above coupled with lower fishing pressure and reduced poaching events (Crivelli et al., 1997a). Therefore, large individuals (that were formerly caught by fishermen) showed increased survival and thus contributed to the breeding pool. That may also be true for other increasing species in Mikri Prespa (e.g. Squalius prespensis), although the lack of reliable fishery statistics make that hypothesis difficult to test. Future collection of such information could further elucidate any relationship with fish abundance.

Considering that Prespa lakes are well known for harboring an abundant community of piscivorous birds, we also tested for any effect of predation on fish species BPUE. Birds can impose substantial mortality on fish (Steinmetz et al., 2003), and Prespa lakes host a diverse avifauna with hundreds of Phalacrocorax carbo breeding pairs, the largest breeding colony of Pelecanus crispus in the world, currently numbering around 1300 breeding pairs as well as several hundred breeding pairs of Pelecanus onocrotalus (Catsadorakis et al., 2015). Both pelicans and cormorants have been found to primarily prey on Alburnus belvica (Pyrovetsi and Economidis, 1998; Grémillet et al., 2012), therefore our hypothesis was that predation could have affected the species BPUE. However, our results did not show any clear effect of predation. Alburnus belvica showed a stable trend in Megali Prespa and seems that thanks to its life history strategy it can cope with both high predation and fishing pressure, as it is also a target species for fishermen (Crivelli, 1992). The only negative effect of predation was shown for Cyprinus carpio in Mikri Prespa led by Microcarbo pygmaeus numbers. Pygmy Cormorants have indeed been found to prey upon Cyprinus carpio in Mikri Prespa (Willems and de Vries, 1998), however, the level on which predation could seriously affect Cyprinus carpio on the population level, remains unclear. Asymmetric predation on different age classes (Beckmann et al., 2006) along with the vulnerability of fish that have been stocked in numerous occasions (Kortan and Adámek, 2011) could play some role but further research is needed to determine if this result is something more than a coincidental relationship, especially since Cyprinus carpio population shows an increasing overall trend.

Overall, the data collected in this study provide a significant contribution to the exploration of the ecology and dynamics of fish community in an ecologically important region. The analysis showed the importance of long-term monitoring in distinguishing between natural variation and direct versus indirect effects of large-scale stressors on fish biomass as well as the improvement in our understanding of freshwater ecosystems, contributing to the preservation and management of freshwater fish populations. Future monitoring efforts should take into account the different species' life histories as they can be differentially impacted by different stressors (long-lived species could need much more time to recover from a decline than short-lived ones; Crivelli, 1992). Intensified efforts to further assess and mitigate the impact of invasive alien species, improve the compatibility of current water management scheme with preservation of littoral habitats, and preparatory actions to help cope with future changes due to climate warming should be undertaken in order to sustain the integrity of fish communities and promote the conservation of natural resources.

\section{Conflict of Interest}

The authors declare no conflict of interest.

\section{Data Availability Statement}

A summary of the data used in this paper is available as Supporting Information. Raw monitoring data are available from the corresponding author (A.J.C) upon reasonable request.

\section{Supplementary Material}

Table S1. Mean biomass per unit effort (BPUE) along with standard error (SE) and range (min-max), for each sampling month and for the annual mean for each lake.

Figure S1. Violin plots depicting the distribution of water level values before and after the beginning of water management in 2005.

Figure S2. Time series of mean annual catches expressed as biomass per unit effort (BPUE), for Cyprinus carpio in Mikri Prespa along with mean spring water level (April-June).

The Supplementary Material is available at https://www.kmaejournal.org/10.1051/kmae/2021027/olm.

Acknowledgments. We are thankful to the Hydroelectric Projects Engineering -Construction Department of the Power Public Corporation S.A., Hellas for providing the meteorological data for the period 2004-2012. We appreciate the constructive comments by Victoria Saravia and one anonymous reviewer on an earlier draft of this paper. The long-term monitoring scheme implemented by the Society for the 
Protection of Prespa was initially funded by the Tour du Valat Foundation, France and subsequently the activities of the Society for the Protection of Prespa were supported with funds from the MAVA Foundation. In 2011 and 2012, the implementation of fish monitoring was also supported by the LIFE project "Fish, Fisheries and European Policy in the Prespa Basin" (LIFE09 INF/GR/000319). After 2018 the study was supported by the Prespa-Ohrid Nature Trust (PONT).

\section{Author Contributions}

AJC and GC conceptualised the study. AB, GC, DN and AJC designed the study. GC, IK, HN, MM and AJC collected the data. $\mathrm{AB}$ analysed the data. $\mathrm{AB}$ drafted the manuscript with input from all other authors.

\section{References}

Allan JD, Abell R, Hogan Z, Revenga C, Taylor BW, Welcomme RL, Winemiller K. 2005. Overfishing of inland waters. BioScience 55: 1041-1051.

Almeida D, Merino-Aguirre R, Vilizzi L, Copp GH. 2014. Interspecific aggressive behaviour of invasive pumpkinseed lepomis gibbosus in iberian fresh waters. PLoS ONE 9: e88038.

Altmann A, Tolosi L, Sander O, Lengauer T. 2010. Permutation importance: A corrected feature importance measure. Bioinformatics 26: 1340-1347.

Arthington AH, Dulvy NK, Gladstone W, Winfield IJ. 2016. Fish conservation in freshwater and marine realms: Status, threats and management. Aquat Conserv 26: 838-857.

Barbieri R, Zogaris S, Kalogianni E, Stoumboudi M, Chatzinikolaou Y, Giakoumi S, Kapakos Y, Kommatas D, Koutsikos N, Tachos V, Vardakas L, Economou AN. 2015. Freshwater Fishes and Lampreys of Greece: An annotated checklist. Monographs on Marine Sciences No. 8. Hellenic Centre for Marine Research: Athens, Greece. p. 130.

Beckmann C, Biro PA, Post JR. 2006. Asymmetric impact of piscivorous birds on size-structured fish populations. Can J Zool 84: $1584-1593$.

Bobori D, Petriki O, Aftzi C. 2019. Fish community structure in the mediterranean temperate lake volvi at two different stages of pumpkinseed invasion: Are natives in threat? Turk J Fish Aquat Sc 19: 1039-1048.

Boy V, Crivelli AJ. 1988. Simultaneous determination of gillnet selectivity and population age-class distribution for two cyprinids. Fish Res 6: 337-345.

Breiman L. 2001. Random forests. Machine Learning 45: 5-32.

Britton J, Pegg J. 2011. Ecology of european barbel barbus barbus: Implications for river, fishery, and conservation management. Rev Fish Sci 19: 321-330.

Catsadorakis G, Malakou M, Crivelli AJ. 1996. The Prespa barbel, Barbus prespensis, Karaman 1924, in the Prespa lakes basin, northwestern Greece. Tour du Valat, Arles, 79p.

Catsadorakis G, Onmus O, Bugariu S, Gül O, Hatzilacou D, Hatzofe O, Malakou M, Michev T, Naziridis T, Nikolaou H, Rudenko A, Saveljic D, Shumka S, S1k1 M, Crivelli AJ. 2015. Current status of the dalmatian pelican and the great white pelican populations of the black sea/mediterranean flyway. Endanger Species Res 27: 119-130.

Catsadorakis G, Papadopoulou E, Petrakos M, Koutseri I. 2018. Status of fisheries at megali prespa lake and mikri prespa lake, greece, based on a census of fishermen's opinions. Environment and Ecology Research 6: 583-592.
Chakravarthy A. 2016. Package 'pRF'. https://cran.r-project.org/web/ packages/pRF

Collen B, Whitton F, Dyer EE, Baillie JE, Cumberlidge N, Darwall WR, Pollock C, Richman NI, Soulsby AM, Böhm M. 2014. Global patterns of freshwater species diversity, threat and endemism. Global Ecol Biogeogr 23: 40-51.

Copp GH, Britton JR, Guo Z, Edmonds-Brown VR, Pegg J, Vilizzi L, Davison PI. 2017. Trophic consequences of non-native pumpkinseed lepomis gibbosus for native pond fishes. Biol Invasions 19: $25-41$.

Cowx I. 2015. Characterisation of inland fisheries in europe. Fisheries Manag Ecol 22: 78-87.

Crivelli AJ. 1990. Fisheries decline in the freshwater lakes of northern Greece with special attention for lake mikri prespa. In: van Densen WLT, Steinmetz B, Hughes RH, editors. Management of freshwater fisheries. Wageningen: PUDOC. p. 230-247.

Crivelli AJ. 1992. Fisheries. In: Gerakis PA, ed. Conservation and management of Greek wetlands. IUCN Publications, Gland, Switzerland.

Crivelli AJ, Catsadorakis G. 1997. Lake Prespa, northwestern Greece. A unique Balkan wetland. Hydrobiologia 351, 1-196.

Crivelli AJ, Catsadorakis G, Malakou M, Rosecchi E. 1997a. Fish and fisheries of the Prespa lakes. Hydrobiologia 351: 107-125.

Crivelli AJ, Malakou M, Catsadorakis G, Rosecchi E. 1997b. Life history and spawning migration of the Prespa nase, Chondrostoma prespensis. Folia Zoologica 46: 37-49.

Cutler DR, Edwards TC, Beard KH, Cutler A, Hess KT, Gibson J, Lawler JJ. 2007. Random forests for classification in ecology. Ecology 88: 2783-2792.

Darwall WRT, Freyhof J. 2016. Lost fishes, who is counting? The extent of the threat to freshwater fish biodiversity. In: Closs GP, Krkosek M, Olden JD, editors. Conservation of freshwater fishes. Cambridge, UK: Cambridge University Press. p. 1-36.

Dudgeon D, Arthington AH, Gessner MO, Kawabata Z-I, Knowler DJ, Lévêque C, Naiman RJ, Prieur-Richard A-H, Soto D, Stiassny ML. 2006. Freshwater biodiversity: Importance, threats, status and conservation challenges. Biol Rev 81: 163-182.

Economidis P, Dimitriou E, Pagoni R, Michaloudi E, Natsis L. 2000. Introduced and translocated fish species in the inland waters of greece. Fisheries Manag Ecol 7: 239-250.

Elith J, Leathwick JR, Hastie T. 2008. A working guide to boosted regression trees. J Anim Ecol 77: 802-813.

Evans J, Murphy M. 2015. Rfutilities: Random forests model selection and performance evaluation.

Evtimova VV, Donohue I. 2016. Water-level fluctuations regulate the structure and functioning of natural lakes. Freshwater Biol 61: 251-264.

Fox MG, Crivelli AJ. 2001. Life history traits of pumpkinseed (Lepomis gibbosus) populations introduced into warm thermal environments. Archiv für Hydrobiologie 150: 561-580.

Gallardo B, Clavero M, Sánchez MI, Vilà M. 2016. Global ecological impacts of invasive species in aquatic ecosystems. Global Change Biol 22: 151-163.

Gozlan RE. 2008. Introduction of non-native freshwater fish: Is it all bad? Fish Fish 9: 106-115.

Grémillet D, Nazirides T, Nikolaou H, Crivelli AJ. 2012. Fish are not safe from great cormorants in turbid water. Aquat Biol 15: $187-194$.

Hatzilacou D. 1993. The distribution of the globally endangered dalmatian pelican pelecanus crispus in greece: Threats pertaining to its habitats and recommendations for protection. Royal Society for the Protection of Birds, Sandy, United Kingdom. 
Hollis G, Stevenson A. 1997. The physical basis of the lake Mikri Prespa systems: geology, climate, hydrology and water quality. Hydrobiologia 351: 1-19.

Kamler E, Keckei H, Bauer-Nemeschkal E. 1998. Temperatureinduced changes of survival, development and yolk partitioning in chondrostoma nasus. J Fish Biol 53: 658-682.

Kazoglou Y, Koutseri I, Malakou M. 2004. Conservation management of wet meadows at the greek part of lake Mikri Prespa. Proceedings of the Balwois.

Kortan J, Adámek Z. 2011. Behavioural response of Carp (Cyprinus carpio, 1.) pond stock upon occurrence of hunting Great cormorant (Phalacrocorax carbo sinensis) flocks. Aquacult Int 19: 121-129.

Lee F, Simon KS, Perry GL. 2017. Increasing agricultural land use is associated with the spread of an invasive fish (Gambusia affinis). Sci Total Environ 586: 1113-1123.

Liaw A, Wiener M. 2002. Classification and regression by randomforest. R News 2: 18-22.

MacDougall AS, Turkington R. 2005. Are invasive species the drivers or passengers of change in degraded ecosystems? Ecology 86: $42-55$.

Matzinger A, Jordanoski M, Veljanoska-Sarafiloska E, Sturm M, Müller B, Wüest A. 2006. Is lake prespa jeopardizing the ecosystem of ancient lake ohrid? Hydrobiologia 553: 89-109.

Olin M, Malinen T, Ruuhijärvi J. 2009. Gillnet catch in estimating the density and structure of fish community-comparison of gillnet and trawl samples in a eutrophic lake. Fish Res 96: 88-94.

Olin M, Rask M, Ruuhljärvi J, Kurkilahti M, Ala-Opas P, Ylönen O. 2002. Fish community structure in mesotrophic and eutrophic lakes of southern Finland: the relative abundances of percids and cyprinids along a trophic gradient. J Fish Biol 60: 593-612.

Parisopoulos G, Malakou M, Giamouri M. 2009. Evaluation of lake level control using objective indicators: The case of Micro Prespa. J Hydrol 367: 86-92.

Perdikaris C, Koutsikos N, Vardakas L, Kommatas D, Simonović P, Paschos I, Detsis V, Vilizzi L, Copp GH. 2016. Risk screening of non-native, translocated and traded aquarium freshwater fishes in greece using fish invasiveness screening kit. Fish Manag Ecol 23: $32-43$.

Persson L, Diehl S, Johansson L, Andersson G, Hamrin S. 1991. Shifts in fish communities along the productivity gradient of temperate lakes - patterns and the importance of size-structured interactions. J Fish Biol 38: 281-293.

Probst WN, Stoll S, Peters L, Fischer P, Eckmann R. 2009. Lake water level increase during spring affects the breeding success of bream Abramis brama (1.). Hydrobiologia 632: 211-224.

Pusey BJ, Arthington AH. 2003. Importance of the riparian zone to the conservation and management of freshwater fish: A review. Mar Freshwater Res 54: 1-16.

Pyrovetsi MD, Economidis PS. 1998. The diet of Dalmatian pelicans (Pelecanus crispus) breeding at lake mikri prespa national park, greece. Israel J Zool 44: 9-17.

R Development Core Team. 2019. R: A language and environment for statistical computing. Vienna, Austria: R Foundation for Statistical Computing. version 3.6.2. Retrieved from https://www.R-project.org/

Radinger J, Britton JR, Carlson SM, Magurran AE, AlcarazHernández JD, Almodóvar A, Benejam L, Fernández-Delgado C, Nicola GG, Oliva-Paterna FJ. 2019. Effective monitoring of freshwater fish. Fish Fish 20: 729-747.
Reid AJ, Carlson AK, Creed IF, Eliason EJ, Gell PA, Johnson PT, Kidd KA, MacCormack TJ, Olden JD, Ormerod SJ. 2019. Emerging threats and persistent conservation challenges for freshwater biodiversity. Biol Rev 94: 849-873.

Rosecchi E, Crivelli AJ, Catsadorakis G. 1993. The establishment and impact of pseudorasbora parva, an exotic fish species introduced into lake mikri prespa (north-western greece). Aquat Conserv 3: 223-231.

Schiemer F, Wieser W. 1992. Epilogue: Food and feeding, ecomorphology, energy assimilation and conversion in cyprinids. In: Wieser W, Schiemer F, Goldschmidt A, Kotrschal K, editors. Environmental biology of european cyprinids. Springer. p. 223-228.

Shumka S, Apostolou A. 2018. Current knowledge on the status of the most common non-indigenous fish species in the transboundary greater prespa lake (albanian side). Acta Zool Bulgar 70: 203-209.

Šmejkal M, Ricard D, Prchalová M, Ríha M, Muška M, Blabolil P, Čech M, Vašek M, Juza T, Herreras AM. 2015. Biomass and abundance biases in european standard gillnet sampling. PLoS ONE 10: e0122437.

Souchon Y, Tissot L. 2012. Synthesis of thermal tolerances of the common freshwater fish species in large western europe rivers. Knowl Manag Aquat Ecosyst 405: 03.

Steinmetz J, Kohler SL, Soluk DA. 2003. Birds are overlooked top predators in aquatic food webs. Ecology 84: 1324-1328.

Stendera S, Adrian R, Bonada N, Cañedo-Argüelles M, Hugueny B, Januschke K, Pletterbauer F, Hering D. 2012. Drivers and stressors of freshwater biodiversity patterns across different ecosystems and scales: A review. Hydrobiologia 696: 1-28.

van Kleef H, van der Velde G, Leuven R, Esselink H. 2008. Pumpkinseed sunfish (Lepomis gibbosus) invasions facilitated by introductions and nature management strongly reduce macroinvertebrate abundance in isolated water bodies. Biol Invasions 10 : $1481-1490$

Wagner B, Wilke T. 2011. Evolutionary and geological history of the balkan lakes ohrid and prespa. Biogeosciences 8: 8.

White ER. 2018. Minimum time required to detect population trends: The need for long-term monitoring programs. BioScience 69: 40-46.

Willems FJ, de Vries E. 1998. Ecological aspects of Pygmy cormorants Phalacrocorax pygmeus at Prespa, Greece, MayAugust 1996. WIWO-report Nr.60.

Wood S. 2018. Mixed GAM computation vehicle with GCV/AIC/ REML smoothness estimation and GAMMs by REML/PQL. R package version 1.8-31. Available from: http://cran.r-project.org/ package $=\mathrm{mgcv}$

Zedler JB, Kercher S. 2005. Wetland resources: Status, trends, ecosystem services, and restorability. Annu Rev Environ Resour 30: 39-74.

Zeileis A, Kleiber C, Krämer W, Hornik K. 2003. Testing and dating of structural changes in practice. Comput Stat Data An 44: 109-123.

Zeileis A, Leisch F, Hornik K, Kleiber C. 2002. Strucchange: An r package for testing for structural change in linear regression models. J Stat Softw 7: 1-38.

Zięba G, Fox MG, Copp GH. 2015. How will climate warming affect non-native pumpkinseed Lepomis gibbosus populations in the uk? PLOS ONE 10: e0135482.

Cite this article as: Bounas A, Catsadorakis G, Koutseri I, Nikolaou H, Nicolas D, Malakou M, Crivelli AJ. 2021. Temporal trends and determinants of fish biomass in two contrasting natural lake systems: insights from a spring long-term monitoring scheme. Knowl. Manag. Aquat. Ecosyst., 422, 28. 